\title{
SUBSTITUSI TEPUNG AMPAS KOPRA PUTIH PADA PEMBUATAN ROTISEBAGAI PANGAN FUNGSIONAL
}

\author{
USE OF WHITE COPRA RESIDUE IN MAKING BREAD AS FUNCTIONAL FOOD \\ Mariati Edam \\ Balai Riset dan Standardisasi Industri Manado \\ Jalan Diponegoro No: 21-22 Manado \\ email: edam.mariati@gmail.com \\ Diterima tgl 05-05-2015, Disetujui tgl 12-05-2015
}

\begin{abstract}
ABSTRAK
Kebutuhan dan tuntutan konsumen terhadap makanan dewasa ini telah berubah dimana konsumen tidak hanya mempertimbangkan segi gizi dan rasa namun cenderung menginginkan makanan yang dapat memberi manfaat kesehatan. Tepung ampas kopra putih dapat dijadikan sumber serat yang memiliki sifat fungsional yang baik bagi kesehatan. Keunggulan tepung ampas kopra putih ini adalah dapat dijadikan sebagai bahan baku untuk pengembangan produk pangan fungsional dalam pembuatan roti. Tujuan dari penelitian ini adalah mengetahui pengaruh substitusi tepung ampas kopra putih pada roti terhadap nilai gizi serta tingkat kesukaan. Metode penelitian yang digunakan adalah penelitian eksperimental dengan Rancangan Acak Lengkap (RAL) satu faktor yaitu konsentrasi tepung ampas kopra putih (0,5, 10, 15 dan 20\%) yang disubstitusikan pada roti untuk mengetahui pengaruhnya terhadap nilai mutu dan tingkat kesukaan roti dengan ulangan sebanyak dua kali. Hasil penelitian menunjukkan bahwa substitusi tepung ampas kopra putih pada roti memberi pengaruh terhadap kadar lemak, protein, karbohidrat dan serat kasar. Roti dengan substitusi $20 \%$ tepung ampas kopra putih memiliki kadar lemak tertinggi $(11,85 \%)$, kadar protein tertinggi $(7,73 \%)$, kadar serat kasar tertinggi (1,06\%), dan kadar karbohidrat terendah yaitu (66,50\%). Dari penelitian ini dapat disimpulkan bahwa substitusi tepung ampas kopra putih berpengaruh terhadap meningkatnya kadar protein, lemak, serat kasar dan menurunkan kadar karbohidrat roti.Tingkat kesukaan roti bersubstitusi tepung ampas kopra putih paling disukai oleh panelis yaitu roti bersubstitusi tepung ampas kopra putih sebanyak $5 \%$ dengan persentase kesukaan $82.8 \%$ dengan kategori suka.
\end{abstract}

Kata Kunci: Ampas kopra putih, pangan fungsional, roti

\section{ABSTRACT}

The needs and demands of today's consumers for food has changed where consumers not only consider about nutrition and taste but also the health benefits. White copra flour residue can be used as a source of fiber which has functional properties that is good for health. White copra flour residue can be used as a basic raw material of functional food products in the manufacture of bread. The aim of this study was to determine the effect of substitution of white copra flour residue on the nutritional value and the level of preference of bread. This research was arranged in a completely randomized design with a treatment of percentage of white copra flour residue $(0,5,10,15$ and 20\%) and repeated twice. The results showed that there was a substitution effect of white copra flour residue in bread on levels of fat, protein, carbohydrate and crude fiber. Bread with flour substitution of $20 \%$ has the highest content of fat (11.85\%), the highest content of protein (7.73\%), the highest content of crude fiber (1.06\%) and the lowest content of carbohydrate (66.50\%). It can be concluded that the substitution of white flour copra residue has significant impact on increasing levels of protein, fat, crude fiber but lowering carbohydratelevel of bread. A level dregs bread flourrr substituted dregs of white copra residue most preferred by the panelist, namely of bread flour substituted dregs of white copra as much as $5 \%$ with a perscentage.

Keywords: White copra, residu, functional food, bread

\section{PENDAHULUAN}

Kopra putih adalah hasil olahan daging kelapa yang memiliki kualitas jauh lebih baik dari kopra asap karena memiliki kelebihan diantaranya warnanya jauh lebih putih dan bersih, relatif bebas dari serangan jamur serta bebas dari aroma yang ditimbulkan dari proses pengasapan sehingga aroma asli 
kopranya jauh lebih dominan. Kopra putih jauh lebih disukai oleh kalangan industri pengolahan kopra karena minyak kelapa yang dihasilkan jernih dan memiliki kualitas yang tinggi dibandingkan kopra asap. Dari pembuatan minyak kelapa, selain menghasilkan minyak juga menghasilkan ampas yang selama ini hanya dikonversi menjadi pakan ternak bahkan ada juga yang terbuang percuma sebagai limbah. Ampas tersebut masih banyak mengandung nilai gizi dan kandungan serat yang tinggi yang sangat baik bagi kesehatan.

Ampas kelapa merupakan sumber protein yang baik, bebas gluten serta memiliki kandungan karbohidrat digestible dan lemak yang rendah. Namun, keunggulan utama tepung ampas kelapa adalah kandungan serat pangannya yang sangat tinggi. Kandungan gizi tepung ampas kelapa yaitu mengandung karbohidrat dalam jumlah yang lebih rendah yaitu sekitar 33,64\% dari tepung terigu $(73,52 \%)$. Kandungan protein tepung ampas kelapa relatif cukup rendah yaitu $5,78 \%$, daripada tepung terigu $(13,51 \%)$. Kandungan lemak tepung ampas kelapa cukup tinggi dibandingkan tepung terigu $(38,23 \%)$. Kandungan serat kasar tepung ampas kelapa cukup tinggi yaitu $15,06 \%$, lebih tinggi dari tepung terigu $(0,25 \%)$. Kandungan serat pangan tak larut sangat tinggi yaitu $(63,66 \%)$, dan serat pangan yang larut sangat rendah $(4,53 \%)^{1}$.

Konsumsi serat rata-rata penduduk Indonesia masih rendah yaitu 10-15 gr/kapita. Padahal kebutuhan ideal serat rata-rata 25-35 gr/hari, sehingga perlu peningkatan asupan serat ${ }^{2}$. Salah satu bahan makanan tinggi serat yaitu ampas kopra putih. Dengan mengubah bentuk menjadi tepung dapat diolah menjadi produk makanan berserat tinggi yang dapat langsung dikonsumsi.

Pola makan dan gaya hidup yang tidak sehat dewasa ini menjadi pemicu timbulnya penyakit seperti obesitas, osteoporosis, diabetes militus, kanker dan penyakit jantung sehingga tuntutandan kebutuhan konsumen terhadap makanan telah berubah, dimana konsumen cenderung menginginkan makanan yang dapat memberikan manfaat untuk kesehatan. Dewasa ini ada kecenderungan orang mengkonsumsi makanan tidak hanya semata-mata mempertimbangkan segi gizi dan rasanya, tetapi juga pengaruh makanan tersebut pada kesehatan tubuhnya.

Saat ini, kebutuhan makanan bergeser menjadi makanan fungsional dan terus berkembang. Selain fungsinya semakin beragam, bentuk produknya sendiri juga semakin bervariasi. Untuk meningkatkan nilai tambah ampas kopra putih sebagai bahan baku pangan (makanan) fungsional maka dapat diolah menjadi tepung kemudian dapat dimanfaatkan sebagai bahan baku dalam industri makanan, misalnya poduk roti. Roti merupakan makanan yang dapat diterima oleh semua lapisan masyarakat karena praktis, mudah didapat, mudah diolah, mudah disajikan dan memiliki harga yang relatif terjangkau ${ }^{3}$. Produk roti pada umumnya berbasis terigu sehingga hampir tidak mengandung serat makanan yang dibutuhkan tubuh. Padahal pengkonsumsi roti tertinggi adalah pada usia rentan penyakit degenerative. Oleh karena itu, perbaikan mutu nutrisi dari segi serat pangan 
produk roti perlu dilakukan dengan memanfaatkan ampas kopra putih.Tujuan dari penelitian ini adalah menganalisis pengaruh substitusi tepung ampas kopra putih terhadap nilai gizi serta tingkat kesukaan dari roti.

\section{BAHAN DAN METODE}

\section{Bahan dan Alat}

Bahan baku yang digunakan dalam penelitian ini adalah tepung ampas kopra putih dan tepung terigu protein tinggi.

Bahan campuran yang digunakan adalah margarin, gula, kuning telur, susu kental manis, vanili, air masak, ragi dan garam.

\section{Metode Penelitian}

Penelitian ini merupakan penelitian eksperimental dengan Rancangan Acak Lengkap satu faktor yaitu konsentrasi tepung ampas kopra putih (0, 5, 10, 15 dan 20\%) yang disubstitusikan pada roti untuk mengetahui pengaruhnya terhadap nilai mutu dan tingkat kesukaan roti dengan ulangan sebanyak dua kali.

\section{Prosedur Pembuatan Roti}

- Siapkan bahan berupa tepung terigu 373 gram, tepung ampas kopra putih sesuai perlakuan, susu kental manis $30 \mathrm{gr}$, kuning telur 1 butir, gula $200 \mathrm{gr}$ ragi $6 \mathrm{gr}$, margarine $100 \mathrm{gr}$ dan air $200 \mathrm{ml}$.

- Mentega, gula, ragi, kuning telur dan susu dicampur kemudian air dan terigu dicampur

- sampai kalis. Adonan didiamkan pada tempat yang ditutup dengan kain selama 60 menit.

- Adonan kemudian dimasukkan dalam cetakan yang sudah diolesi margarin dan tepung terigu dan didiamkan kembali selama 90 menit dengan ditutupi dengan kain.

- Adonan yang sudah mengembang dipanggang dalam oven pada suhu $200^{\circ} \mathrm{C}$ hingga matang.

\section{Variabel Pengamatan}

Pengamatan terhadap roti bersubstitusi tepung ampas kopra puti yaitu: kadar protein, karbohidrat, lemak dan kadar serat kasar serta uji organoleptik meliputi tekstur, rasa, aroma dan warna mengunakan uji kesukaan skala hedonic dengan skala $1=$ tidak suka, $2=$ agak suka, $3=$ suka, $4=$ sangat suka. Data yang diperoleh diamati menggunakan analisis varians dan dilanjutkan dengan beda nyata terkecil apabila ada pengaruh perlakuan terhadap parameter yang diukur.

\section{HASIL DAN PEMBAHASAN}

Hasil analisis kadar lemak (Gambar1), tertinggi terdapat pada roti dengan substitusi tepung ampas kelapa $20 \%$ yaitu $11,85 \%$ dan terendah pada roti tanpa substitusi ampas kopra putih yaitu 10,32\%. Terlihat bahwa meningkatnya kadar lemak roti seiring dengan penambahan substitusi tepung kopra putih. Berdasarkan analisis varians substitusi tepung ampas kopra putih memberi pengaruh sangat nyata terhadap kadar lemak roti $(p<0,01)$. Hasil uji beda Tukey pengaruh substitusi tepung ampas kopra putih terhadap kadar lemak roti menunjukkan bahwa roti tanpa substitusi tepung ampas kopra putih sangat berbeda nyata dengan roti bersubstitusi tepung ampas kopra putih, substitusi ampas kopra putih 5 dan 10\% berbeda nyata dengan roti bersubstitusi 
tepung ampas kopra putih 15 dan 20\%. Hal ini dipengaruhi oleh tepung ampas kopra putih mengandung lemak lebih besar dibanding tepung terigu.

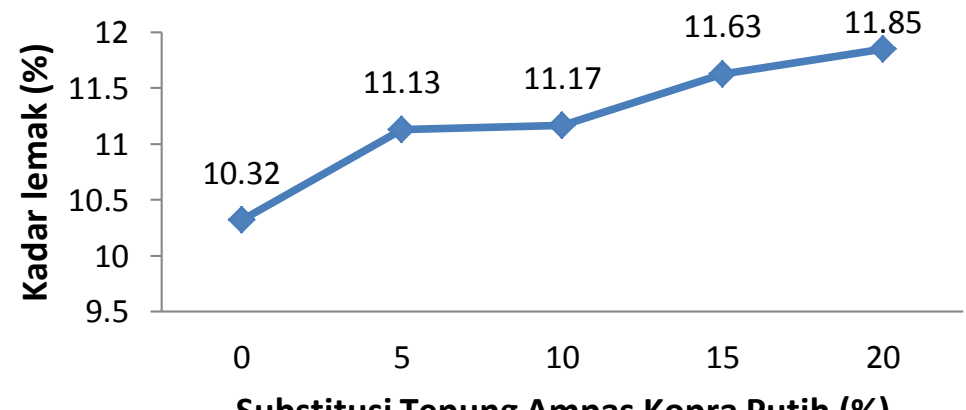

Substitusi Tepung Ampas Kopra Putih (\%)

Gambar 1.Pengaruh Substitusi Tepung Ampas Kopra Putih Terhadap Kadar Lemak Roti.

Selain itu, bahan lain dari roti seperti margarine, susu kental manis dan telur juga penyumbang lemak terhadap produk roti tersebut. Lemak tepung ampas kopra putih yaitu $8,21 \%{ }^{4}$. Rendahnya lemak tepung ampas disebabkan karena proses pengepresan saat pengolahan tepung ampas. Sebagai bahan pangan berkadar lemak rendah cocok dikonsumsi oleh golongan konsumen yang kegemukan (obesitas), beresiko terhadap kolestrol dan jantung koroner ${ }^{5}$.Dalam pengolahan pangan, lemak memiliki sifat fungsional diantaranya mempengaruhi flavor, tekstur, warna, kelembutan, emulsifikasi, dan medium pindah panas dalam proses pemasakan ${ }^{6}$.

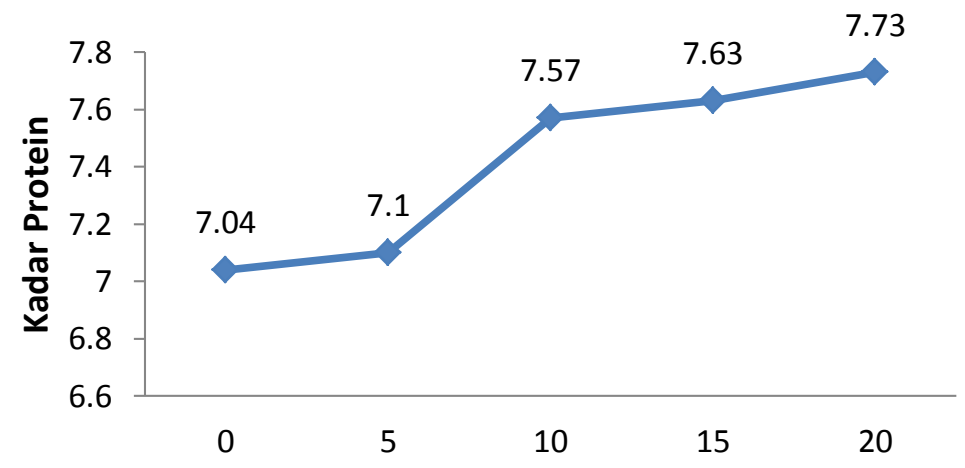

Substitusi Tepung Ampas Kopra Putih (\%)

Gambar 2. Pengaruh Substitusi Tepung Ampas Kopra Putih Terhadap Kadar Protein Roti.

Hasil analisis kadar protein roti bersubastitusi tepung ampas kopra putih (Gambar 2) berkisar 7,04-7,73\%. Berdasarkan Gambar 2, terlihat bahwa meningkatnya kadar protein roti seiring dengan penambahan substitusi tepung kopra putih. Berdasarkan analisis varians substitusi tepung ampas kopra putih memberi pengaruh sangat nyata terhadap kadar protein roti $(p<0,01)$. Hasil uji beda Tukey 
pengaruh substitusi tepung ampas kopra putih terhadap kadar protein roti menunjukkan bahwa roti bersubstitusi tepung ampas kopra putih 0 dan $5 \%$ sangat berbeda nyata dengan roti bersubstitusi tepung ampas kopra putih 10,15 dan 20\%. Terlihat bahwa tepung ampas kopra putih bukan merupakan sumber protein karena kandungan proteinnya yang sangat rendah. Kadar protein tepung ampas kopra putih yaitu $6,27 \%{ }^{4}$. Protein tepung ampas kopra putih tergolong rendah. Tepung berprotein rendah (pastry flour) memiliki kadar protein $6-8 \%{ }^{7}$. Hal ini secara visual terlihat dari daya kembang roti yang dihasilkan yaitu semakin bertambahnya substitusi tepung ampas kopra putih maka roti yang dihasilkan menunjukkan adanya penurunan.Tepung kelapa memberikan pengaruh yang kurang baik pada kualitas roti. Hal ini disebabkan tepung kelapa tidak mengandung gluten. Kandungan gluten pada tepung menyebabkan tepung memiliki kapasitas foaming dan gelatinisasi yang tinggi. Produk yang dihasilkan dari bahan tepung tanpa gluten tidak terlalu mengembang namun padat (tidak berongga) ${ }^{8}$.

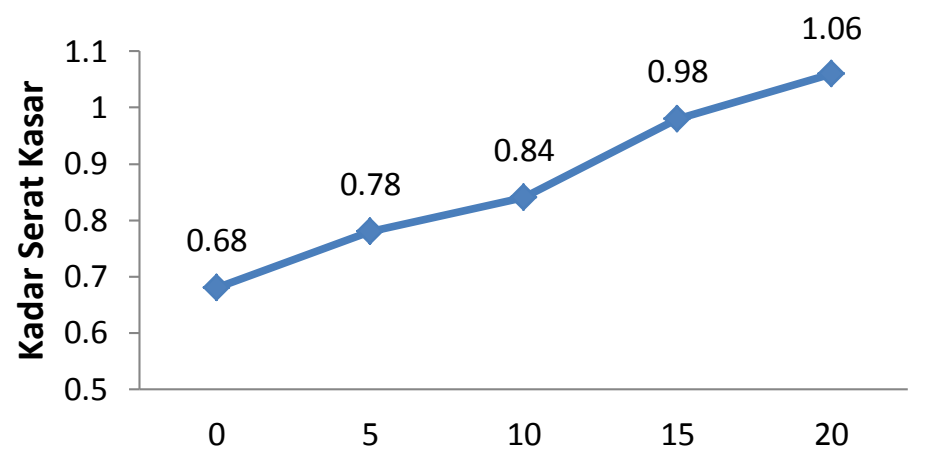

Substitusi Tepung Ampas Kopra Putih (\%)

Gambar 3. Pengaruh Substitusi Tepung Ampas Kopra Putih Terhadap Kadar Serat Kasar Roti.

Hasil analisis kadar serat kasar (Gambar 3), tertinggi terdapat pada roti dengan substitusi tepung ampas kelapa $20 \%$ yaitu $1,06 \%$ dan terendah pada roti tanpa substitusi ampas kopra putih yaitu 0,68\%.Berdasarkan Gambar 3, terlihat bahwa meningkatnya kadar serat kasar roti seiring dengan penambahan substitusi tepung kopra putih. Berdasarkan analisis varians substitusi tepung ampas kopra putih memberi pengaruh sangat nyata terhadap kadar Iserat kasar $(p<0,01)$. Hasil uji beda Tukey pengaruh substitusi tepung ampas kopra putih terhadap kadar serat kasar roti menunjukkan bahwa roti bersubstitusi tepung ampas kopra putih $20 \%$ tidak berbeda nyata dengan roti bersubstitusi tepung ampas kopra putih $15 \%$ dan berbeda nyata dengan roti tepung ampas kopra putih lainnya. Tepung ampas kopra putih mengandung serat kasar yang cukup tinggi $(8,53 \%)^{4}$, lebih tinggi dari tepung terigu(0.25\%). Hal ini menunjukkan bahwa pengolahan ampas kopra putih menjadi tepung sebagai sumber serat pangan sangat baik.Karena itu tepung ampas kopra putih dapat dijadikan sumber 
serat pangan yang ditemukan cukup tinggi dibandingkan dengan serat pangan dari sumber lain yang terdapat secara komersial dan serat pangan tersebut sebagai komponen fungsional pangan yang memberi efek positif pada kesehatan.

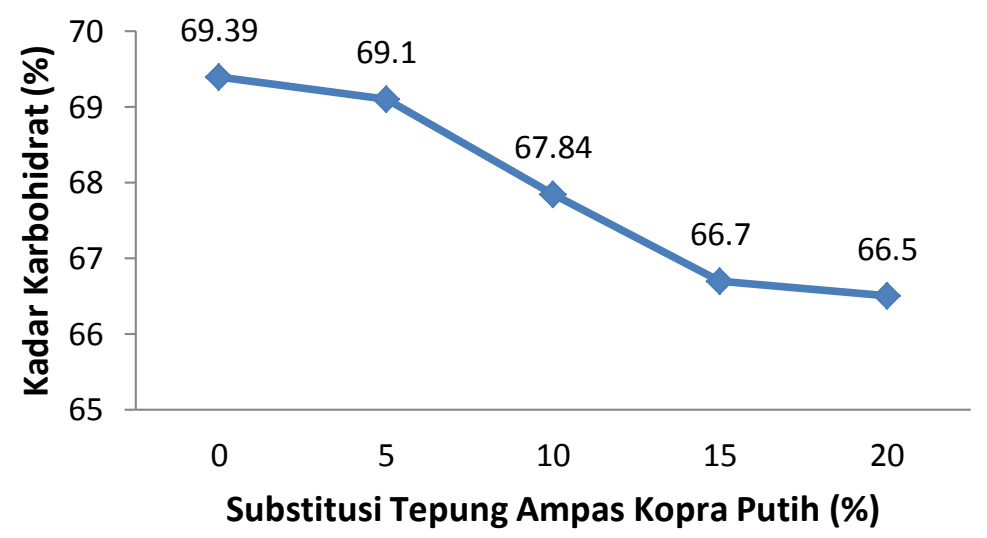

Gambar 4. Pengaruh Substitusi Tepung Ampas Kopra Putih Terhadap Kadar Lemak Roti.

Hasil analisis kadar karbohidrat roti bersubastitusi tepung ampas kopra putih (Gambar 4) berkisar 66,5-69,39\%. Berdasarkan Gambar 4, terlihat bahwa menurunnya kadar karbohidrat roti seiring dengan penambahan substitusi tepung kopra putih. Berdasarkan analisis varians substitusi tepung ampas kopra putih memberi pengaruh sangat nyata terhadap kadar protein roti $(p<0,01)$. Hasil uji beda Tukey pengaruh substitusi tepung ampas kopra putih terhadap kadar protein roti menunjukkan bahwa setiap perlakuan memberi perbedaan yang nyata terhadap kadar karbohidrat roti. Kadar karbohidrat roti secara keseluruhan menurun seiring dengan meningkatnya substitusi tepung ampas kelapa. Hal ini dipengaruhi oleh kadar karbohidrat tepung ampas kopra putih lebih rendah dari tepung terigu. Tepung terigu merupakan bahan dasar aneka produk makanan yang berasal dari biji gandum. Selain banyak mengandung protein, tepung terigu juga mengandung banyak pati, yaitu karbohidrat kompleks yang tidak larut dalam air ${ }^{7}$.

Roti substitusi tepung ampas kopra putih meliputi penilaian tekstur, rasa, aroma dan warna disajikan pada Tabel 1.

Tabel 1. Pengaruh Substitusi Tepung Ampas Kopra Putih Terhadap Tingkat Kesukaan Roti.

\begin{tabular}{|c|c|c|c|c|c|}
\hline \multirow{2}{*}{$\begin{array}{c}\text { Perlakuan } \\
\text { (\%) }\end{array}$} & \multicolumn{4}{|c|}{ Indikator Sensorik } & \multirow{2}{*}{$\%$} \\
\hline & Warna & Aroma & Rasa & Tekstur & \\
\hline 0 & $2,95^{\mathrm{bc}}$ & $3,16^{c}$ & $3,55^{\mathrm{e}}$ & $4,50^{\mathrm{e}}$ & 88.5 \\
\hline 5 & $2,87^{b}$ & $3,08^{b}$ & $3,10^{d}$ & $4,20^{d}$ & 82,8 \\
\hline 10 & $2,95^{b c}$ & $3,13^{c}$ & $2,92^{\mathrm{C}}$ & $3,40^{c}$ & 77,5 \\
\hline 15 & $3,00^{c}$ & $3,08^{b}$ & $2,84^{b}$ & $2,80^{b}$ & 73,3 \\
\hline 20 & $3,08^{a}$ & $4,20^{\mathrm{a}}$ & $2,66^{a}$ & $2,33^{a}$ & 51.7 \\
\hline
\end{tabular}


Ket. Superskrip yang tidak sama pada setiap kolom menunjukan perbedaan yang nyata.

Roti merupakan makanan padat yang bertekstur lembut dan merupakan salah satu jenis makanan yang berbentuk sponge, yaitu makanan yang sebagian besar volumenya tersusun dari gelembung-gelembung gas ${ }^{9}$. Berdasarkan Tabel 1, dapat diketahui bahwa tingkat kesukaan panelis berdasarkan indikator warba, aroma, rasa dan tekstur roti bersubstitusi tepung ampas kopra putih dari penelitian ini yaitu paling disukai oleh panelis adalah roti bersubstitusi tepung ampas kopra putih sebanyak $5 \%$, walaupun sebenarnya panelis lebih menyukai roti tanpa substitusi tepung ampas kopra putih dengan persentase kesukaan $82,8 \%$ (kategori suka) dan termasuk dalam kriteria tinggi. Dari hasil penelitian (Tabel 1) dapat diringkas sebagai berikut:

- Warna yang terbaik adalah roti bersubstitusi tepung ampas kopra putih sebanyak $20 \%$.

- Aroma yang terbaik adalah roti bersubstitusi tepung ampas kopra putih sebanyak $20 \%$.

- Rasa yang terbaik adalah adalah roti bersubstitusi tepung ampas kopra putih sebanyak $5 \%$.

- Tekstur yang terbaik adalah adalah roti bersubstitusi tepung ampas kopra putih sebanyak $5 \%$.

Berdasarkan analisis varians substitusi tepung ampas kopra putih (Tabel1) memberi pengaruh sangat nyata terhadap terhadap warna roti $(p<0,01)$. Hasil uji beda Tukey pengaruh substitusi tepung ampas kopra putih terhadap warna roti menunjukkan bahwa roti bersubstitusi tepung ampas kopra putih $20 \%$ memberi pengaruh yang berbeda nyata dengan roti bersubstitusi tepung ampas kopra putih lainnya. Hal ini menunjukkan bahwa warna kuning kecoklatan dari roti memberi nilai disukai oleh panelis. Penggunaan substitusi sebanyak $20 \%$ tepung ampas menunjukkan tingkat kesukaan tertinggi, walaupun sebenarnya semua perlakuan menunjukkan kategori disukai. Hal ini dipengaruhi oleh sifat fungsional dari lemak tepung ampas kopra putih.Dalam pengolahan pangan, lemak memiliki sifat fungsional diantaranya mempengaruhi warna ${ }^{6}$.

Hasil analisis varians substitusi tepung ampas kopra putih (Tabel1) memberi pengaruh sangat nyata terhadap terhadap aroma roti $(p<0,01)$. Hasil uji beda Tukey pengaruh substitusi tepung ampas kopra putih terhadap aroma roti menunjukkan bahwa roti bersubstitusi tepung ampas kopra putih $20 \%$ memberi pengaruh yang berbeda nyata dengan roti bersubstitusi tepung ampas kopra putih lainnya.Tepung ampas kopra putih memiliki aroma yang harum khas kelapa sehingga mengakibatkan roti yang disubstitusi dengan tepung tersebut memiliki aroma yang khas kelapa ${ }^{11}$. Berdasarkan analisis varians substitusi tepung ampas kopra putih (Tabel1) memberi pengaruh sangat nyata terhadap terhadap rasa roti $(p<0,01)$. Hasil uji beda Tukey pengaruh substitusi tepung ampas kopra putih terhadap rasa menunjukkan bahwa setiap substitusi tepung ampas kopra putih memberi pengaruh yang berbeda pada roti.Hal ini disebabkan karena tepung ampas kopra putih memberi kontribusi citarasa kelapa yang gurih. Namun, semakin banyak 
substitusi tepung ampas kopra putih semakin tidak disukai. Kandungan serat yang dimiliki tepung ampas kopra putih yang sangat tinggi akan menimbulkan rasa 'berpasir' seiring dengan semakin banyak substitusi yang dilakukan. Hal ini menyebabkan kesukaan panelis terhadap rasa dari roti semakin tidak suka $^{10}$.

Berdasarkan analisis varians substitusi tepung ampas kopra putih (Tabel1) memberi pengaruh sangat nyata terhadap terhadap tekstur roti $(p<0,01)$. Hasil uji beda Tukey pengaruh substitusi tepung ampas kopra putih terhadap tekstur menunjukkan bahwa setiap substitusi tepung ampas kopra putih memberi pengaruh yang berbeda pada roti. Terlihat bahwa semakin banyaknya substitusi tepung ampas kopra putih maka tekstur yang dihasilkan semakin tidak disukai. Hal ini disebabkan karena tekstur roti akan semakin padat dan berserat seiring dengan semakin banyaknya tepung ampas kopra putih yang disubstitusi. Secara visual terlihat bahwa semakin banyak penggunaan tepung ampas kopra putih menghasilkan daya kembang roti berkurang. Semakin banyak substitusi tepung ampas kopra putih akan semakin padat (tidak berongga). Hal ini dipengaruhi oleh rendahnya kandungan gluten yang dimiliki oleh roti. Gluten mempunyai sifat fisik yang elastis dan dapat mengembang. Rendahnya kandungan gluten mengakibatkan rongga-rongga adonan yang terbentuk hanya sedikit sehingga roti yang dihasilkan bertekstur padat dan kurang mengembang. Di samping itu, tepung ampas kelapa juga memiliki kandungan serat yang tinggi sehingga semakin banyak tepung ampas kelapa yang disubstitusi akan mengakibatkan tekstur yang sangat berserat ${ }^{10}$.

\section{KESIMPULAN}

Substitusi tepung ampas kopra putih memberi pengaruh sangat nyata terhadap kadar lemak, protein, serat kasar, karbohidrat.Tingkat kesukaan roti bersubstitusi tepung ampas kopra putih paling disukai oleh panelis yaitu roti bersubstitusi tepung ampas kopra putih sebanyak $5 \%$ dengan persentase kesukaan $82.8 \%$ dengan kategori suka.

\section{DAFTAR PUSTAKA}

1. Engelen. A. Pemanfaatan Ampas Kelapa yang Diolah Menjadi Tepung Kelapa. 2011;:IPB - Bogor.

2. Muthia F. Pengaruh Substitusi Tepung Ampas kelapa Terhadap Kandungan Gizi, Serat dan Volume pengembangan Roti. Undip-Semarang; 2013.

3. Wahyudi WR dan H. Pengaruh Substitusi Parsial Tepung Terigu dengan Tepung Pati Gayong dan Penambahan Sodium Stearoyl2 lactylat Terhadap Mutu Roti Tawar. 2007;

4. Kaseke Hilda, Edam M, Ringkuangan S, Sulawerti N, Wowor O TJ. Pemanfaatan Ampas Kopra Putih Untuk Pangan Fungsional. Manao; 2013.

5. Trinidad et.al. Dietary Fiber From Coconut Flour: A Functional Food. Innovative Food Science and Energing Tecnologies. 2006.

6. Kusnandar. F. Kimia Pangan, Komponen Makro. Jakarta: Dian Rakyat; 2010.

7. E. Salim. Mengolah Singkong Menjadi Tepung Mocaf: Bisnis alternatif Pengganti Terigu. Yogyakarta: Lily Publiser; 2011.

8. Rindengan KS dan B. Potensi Tepung Ampas Kelapa Sebagai Sumber Pangan dan Manfaatnya Untuk Kesehatan. Balai Penelit Tanam Kelapa dan Palma Lain. 2011; 
9. Mudjajanto E. dan LNY. Seni Agrotekno Membuat Aneka Roti. Jakarta: Swadaya; 2007.

10. Ryyani. Z. Dini. Pengaruh Substitusi Tepung Ampas Kelapa Terhadap Nilai Indeks

11. Fajri PM. Kandungan Gizi dan Sifat Fisik Tepung Ampas Kelapa Sebagai Bahan Pangan Sumber Serat. Teknobuga. 2010;2.
Glikemik, bebas Glikemik dan Tingkat kesukaan Roti. Undip-Semarang; 2013. 
